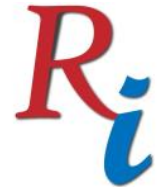

Asia Proceedings of Social Sciences

(APSS)

www.readersinsight.net/APSS

\title{
EVALUATION OF E-HAILING DRIVER'S WELFARE: AN ANALYSIS ON DRIVER'S REVENUE AND EXPENSES
}

\author{
Goh Hong Lip*
}

Faculty of Accountancy and Management

Universiti Tunku Abdul Rahman, Selangor

Malaysia

gohhl@utar.edu.my

\section{Dorothea Chee Ke Jing}

Faculty of Accountancy and Management

Universiti Tunku Abdul Rahman, Selangor

Malaysia

dorotheaachee@1utar.my

\section{Emily Chow Yan Chi}

Faculty of Accountancy and Management

Universiti Tunku Abdul Rahman, Selangor

Malaysia

ycchow_614@hotmail.com

*Corrosponding author's Email: gohhl@utar.edu.my

Peer-review under responsibility of 4th Asia International Multidisciplinary Conference 2020 Scientific Committee http://connectingasia.org/scientific-committee/ (C) 2020 Published by Readers Insight Publisher, lat 306 Savoy Residencia, Block 3 F11/1,44000 Islamabad. Pakistan, editor@readersinsight.net This is an open access article under the CC BY-NC-ND license (http://creativecommons.org/licenses/by-nc-nd/4.0/). 


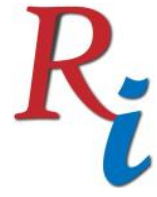

Asia Proceedings of Social Sciences

(APSS)

www.readersinsight.net/APSS

\section{A b s t r a c t}

This study estimates the economics of e-hailing drivers by analysing the results from a survey conducted on 254 drivers focused on their revenue and also expenses. Revenue includes basic fares and tips they collected while driving, while expenses can be further dived into operational expenses, taxes and social security packages (socso, epf, insurance). Results estimated that drivers average 120 trips per week and average yearly revenue can up to MYR 59,184 inclusive of tips. However, factoring the operational expenses, their net profit per year can drop to MYR 10,107 - 13,983 subject to taxes, insurance and social security commitments. The net profit of driver is way less than the Malaysia minimum wage policy. Social securities were perceived as secondary for most drivers when it comes to welfare concerns. Policy implication were discussed with concerns of over-regulations will diminish the e-hailing industry and the welfare of drivers indirectly.

\section{Rese a r ch H igh I ight s}

1. This study provides evidence on the economics of e-hailing drivers by focusing on their revenue and expenses.

2. This study found out that driving e-hailing services in long run might be not sustainable, as the revenue is offset by the costs.

3. Driving e-hailing service full-time will be challenging, perhaps it is more suitable for parttime drivers.

\section{Research Objectives}

The objective of this study is to analyse and understand the welfare status of e-hailing drivers in Malaysia. Specifically, this proposed research aims to:

1. To assess the revenue-expenses of the e-hailing drivers in Malaysia.

2. To evaluate the sustainability of e-hailing services in Malaysia.

\section{Methodology}

Estimation method was adapted from Zoepf et al. (2018) estimation on ride hailing economics. Survey was conducted and the questionnaire were distributed to 254 e-hailing drivers in Klang Valley region, Malaysia between January-February 2020 to obtain their self-reported revenue and costs. Revenue were divided into to fares and tipping. Expenses were divided to tax, maintenance, licensing, and fuel costs. Social securities packages such as insurance, SOCSO, 


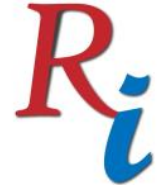

Asia Proceedings of Social Sciences

(APSS)

www.readersinsight.net/APSS

and EPF were treated as additional costs as well. The average revenue, costs, and social securities were used to estimate the profits of the drivers. Two estimation scenarios were used to estimate the net profit, I.e., 1) by substituting the RM0.64 per km mileage claim (MEF 2015) as the average of maintenance and fuel costs; and 2) by calculating the maintenance and fuel costs separately as expenses.

\section{Results}

Initial results showed the e-hailing drivers driving $5,885 \mathrm{~km}$ per month, mostly work 48 hours per week, which equivalent to six full working days. Their fares and tipping averages RM4,500 per month and RM4.50 per tip respectively with an average of 20 trips per day. By assuming $20 \%$ of their trips getting tips, the average yearly revenue of a driver is around RM59,184. By substituting mileage claim as the costs of maintenance and fuel (scenario 1), the yearly earnings of drivers can drop to RM13,983. In scenario 2, the yearly earnings can further dropped to RM10,177. Both estimations suggest that average driver could earn less than the national minimum wage of RM1,200 (Federal Government Gazette 2020) inclusive of operational expenses.

\section{Findings}

The results indicate that driving e-hailing service in Malaysia might not be sustainable in long run, as the average net profit of drivers are comparable to minimum wage set by the government. At the same time, this implies that the gig economy of e-hailing service might be more suitable as part-time job rather than a full-time one. Perhaps, the policy makers should have a new perspective in regulating future policies in regards to the development of e-hailing industries, as additional regulations might further diminish the already weak net income of drivers.

\section{Acknowledgement}

This study would not be done successfully without the assistance of my group mates and my two wonderful students: Dorothea and Emily. I would also like to thank Universiti Tunku Abdul Rahman (UTAR) Institute of Postgraduate Studies and Research (IPSR) for the research grant (IPSR/RMC/UTARRF/2019-C1/G05) provided for us to complete the study.

\section{References}

Zoepf, S., Chen, S., Adu, P., \& Pozo, G. (2018). The economics of ride-hailing: Driver revenue, expenses and taxes. Cambridge: MIT CEEPR. 


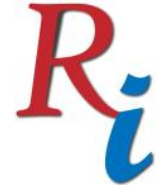

\section{Asia Proceedings of Social Sciences (APSS) \\ www.readersinsight.net/APSS}

MEF (2015). MEF Allowances \& Reimbursements Survey, 2015. Retrieved from http://www.mef.org.my/kc/surveysdetails.aspx?ID=14

Federal Government Gazette (2020). Minimum wages order 2020. Retrieved from http://www.federalgazette.agc.gov.my/outputp/pua_20200110_P.U.\%20(A)\%205. pdf

Author's Biography:

Goh Hong Lip is a lecturer at the Faculty of Accountancy and Management, UTAR. He obtained his PhD. In Evironmental Management from Universiti Kebangsaan Malaysia (UKM), Malaysia. Besides teaching duty, he's also an active member from UTAR's Belt and Road Strategic Research Centre (BRSRC) focuses on environmental sustainability and various social-economic issues. He is interested in how the ever growing inter-connectivity may shape people's perspective on the economy, social, cultural and political issues in a holistic context. 